
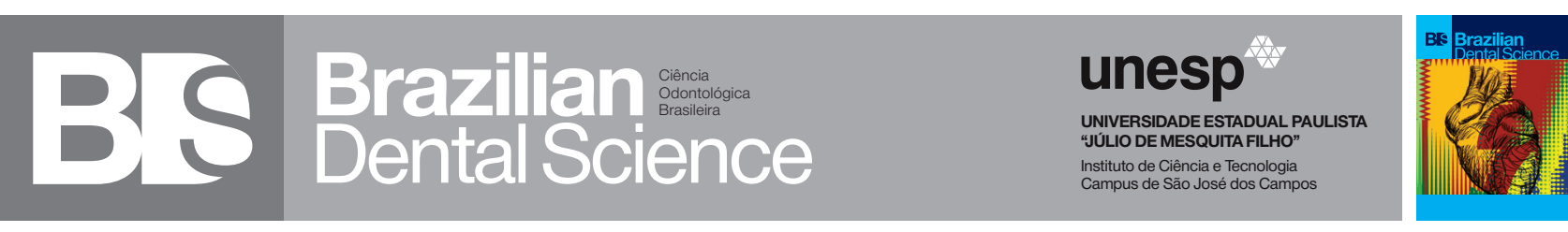

\title{
Knowledge, Behaviour and Practices regarding Oral Health among Public School Students
}

\author{
Conhecimento, comportamento e práticas em saúde bucal apresentados por escolares da Rede Pública de Ensino \\ Luiza Maria Mendes LEME ${ }^{1}$, Bruna Gonçalves Alvarenga de OLIVEIRA ${ }^{1}$, Daniela Maria de Toledo UNGARO ${ }^{1}$, Eduardo Galera da \\ SILVA $^{2}$, Ana Paula Martins GOMES ${ }^{1}$ \\ 1 - São Paulo State University (Unesp) - Institute of Science and Technology - São José dos Campos - Department of Restorative Dentistry \\ - SP - Brazil. \\ 2 - São Paulo State University (Unesp) - Institute of Science and Technology - São José dos Campos - Department of Social and Pediatric \\ Dentistry - SP - Brazil.
}

\begin{abstract}
Objective: The aim of this study was to assess the knowledge, behaviour and practices regarding caries lesions, periodontal disease, preventive measures, diet and oral hygiene among public school students by using specific questionnaire and then guide them on the main educational and preventive methods for oral health. Material and Methods: A total of 376 students aged between 11 and 15 years old were evaluated. The students answered a questionnaire and watched a 10-minute educational video on tooth-brushing techniques, use of dental floss and diet. All the participants were given toothbrushes, dentifrice and dental floss. The resulting data were submitted to descriptive statistical analysis. Results: It was found that $54.26 \%$ of the school students were female, $95.21 \%$ had knowledge on caries lesions and only $15.96 \%$ know about periodontal disease. The surgeon-dentist was pointed out by $66.34 \%$ of the students as the responsible for guiding them on oral hygiene, with lack of hygiene being accounted for caries lesions and periodontal disease $(64.09 \%$ and $38.30 \%$, respectively). Toothbrush, dentifrice and dental floss were the most used resources for oral hygiene by $72.34 \%$ of the participants. Dental floss was used by $42.29 \%$ of the students, whereas $38.64 \%$ fail in doing so claiming they do not know how to use it. Conclusion: The school students showed knowledge on educational and preventive methods for oral health, but with some deficiencies; the majority of them were given guidelines on how to avoid oral problems by a surgeondentist; it is necessary to emphasise the importance of using dental floss in educational programs aimed at modifying the students' behaviour and practices regarding oral health.
\end{abstract}

\section{KEYWORDS}

Dental caries; Education on oral health education; Oral health; Children health; Public health.

\section{RESUMO}

Objetivo: O objetivo deste estudo foi avaliar o conhecimento, comportamento e práticas de escolares da Rede Pública de Ensino sobre cárie, doença periodontal, medidas preventivas, dieta e higiene bucal por meio de um questionário específico e, posteriormente orientá-los sobre os principais métodos educativos e preventivos em saúde bucal. Material e Métodos: Foram avaliados 376 estudantes com idade entre 11 e 15 anos. Os escolares responderam um questionário e assistiram um vídeo educativo com duração de 10 minutos sobre técnicas de escovação, utilização do fio dental e dieta. Todos os alunos participantes receberam uma escova, creme dental e fio dental. Os dados obtidos foram submetidos à análise estatística descritiva. Resultados: Os resultados mostraram que $54,26 \%$ dos escolares eram do gênero feminino, $95,21 \%$ apresentaram conhecimento sobre cárie e apenas $15,96 \%$ sobre doença periodontal. O Cirurgião Dentista foi apontado como responsável pela orientação sobre higienização bucal por $66,34 \%$ dos escolares, sendo a falta de higiene responsabilizada tanto pela etiologia da cárie como da doença periodontal $(64,09 \%$ e $38,30 \%$, respectivamente). Escova, creme dental e fio dental são os recursos mais utilizados para higienização bucal por $72,34 \%$ dos entrevistados. O fio dental é utilizado por $42,29 \%$ dos alunos, e $38,64 \%$ não o utilizam alegando que não sabem utilizar. Conclusão: Os escolares avaliados apresentam conhecimento sobre métodos educativos e preventivos em saúde bucal, com algumas deficiências; a maioria dos escolares teve acesso a orientações sobre como evitar problemas bucais por meio do Cirurgião Dentista; é necessário enfatizar a importância do uso do fio dental nos programas educativos para modificar o comportamento e as práticas dos escolares em relação à saúde bucal.

\section{PALAVRAS-CHAVE}

Cárie dentária; Educação em saúde bucal; Saúde bucal; Saúde da criança; Saúde pública. 


\section{INTRODUCTION}

Car aries disease and periodontal disease are admittedly the most common oral diseases, being one of the main public health problems as they affect the individual's quality of life. The strategies for control and prevention of dental caries as well as of periodontal disease should be aimed at the elimination of aetiological factors, with adhesion to adequate behaviour regarding oral hygiene, diet and fluoride use being essential.

Oral problems can restrain the school activities and seem to be more evident among public school students [1] compared to their private counterparts [2]. As adolescents aged between 11 to 15 years old are mostly inserted in the educational environment, the school is the suitable educational and social place for them to develop knowledge and change behaviours [3].

Many health promotion programs have been implemented in a variety of settings [4-9]. However, school is highlighted as a facilitator in the health promotion and disease prevention [6] because of its infra-structure, which makes acquisition of new knowledge easier and consequently enables development and establishing of healthy habits [10].

Educational programs in schools play a very important role in the students' behaviour as they can help reducing the prevalence of dental caries, gingival bleeding and presence of bacterial plaque [11]. For succeeding in these educational programs, the individuals should be made conscious about their role in the oral healthcare and this can only be achieved by implementing motivational preventive and guiding methods for control of bacterial plaque [12]. Nevertheless, motivation can be considered the driving force in this dynamics as the students' early experiences, family, culture, values and social level are all influential, including their dentists [8,13-16].

Considering that school is an important site for aggregating health, education, motivation and knowledge diffusion, the objective of this study was to assess the knowledge, behaviour and oral health practices of 376 public school students regarding dental caries, periodontal disease and preventive measures for oral health maintenance.

\section{METHODS AND MATERIALS}

This study was evaluated and then approved by the local research ethics committee (ICT/SJC UNESP) according to protocol number 042/2008$\mathrm{PH} / \mathrm{CEP})$. The target population was composed of students enrolled in the 6th to 9th grades of the public state elementary school João Cursino located in the city of São José dos Campos. A total of 376 students aged between 11 and 15 years old were evaluated, who answered objective questions on dental caries, periodontal disease, oral hygiene measures, frequency of daily oral hygiene, diet, and behaviour and practices related to oral health.

The questionnaire was elaborated with direct questions in order to facilitate the students' comprehension and to contribute to clear information sharing. Prior to the application of the questionnaire, the students were instructed on the objectives of the study and any doubts clarified. The questionnaire was voluntarily and individually answered by the students, who could leave the study at any time. After completing the questionnaire, the students watched 10-min educational video on the main oral health preventive measures, including guidelines on diet and oral hygiene for preventing dental caries and periodontal disease. All the school students participating in the study were given an oral hygiene kit containing soft-bristled toothbrush, fluoride dentifrice and dental floss.

According to Sorensen et al. [17], the variables were distributed into four groups according to Sorensen et al. [17], namely: personal determinants, healthcare services, knowledge, behaviour and practices related to health.

\section{RESULTS}

The data obtained from the questionnaire were entered into electronic spreadsheets (Excel, Microsoft) and then statistically analysed (descriptive analysis), including absolute (n) and relative frequencies (\%).

Table 1 lists the results for personal determinants and use of healthcare services, while Box 1 shows the frequency of answers given by the students to questions on their knowledge, behaviour and practices regarding oral health. 
Table I - Description of the experimental design, techniques specifications of the materials used and treatment time

\begin{tabular}{|cc|}
\hline $\begin{array}{c}\text { Personal determinants } \\
\text { Female }\end{array}$ & Distribution (n and \%) \\
\hline Male & $204(54.26 \%)$ \\
\hline Total & $172(45.74 \%)$ \\
\multicolumn{2}{|c|}{ Use of healthcare service } \\
\multicolumn{2}{c|}{ Last visit to the surgeon-dentist } \\
\hline 1year or less & $256(68.09 \%)$ \\
\hline More than 1 years & $76(20.21 \%)$ \\
\hline Did not answer the question & $44(11.70 \%)$ \\
\hline Total & $376(100 \%)$ \\
\hline
\end{tabular}

Box 1-Distribution of the answers given by the students to questions on knowledge, behaviour and practices regarding oral health.

\begin{tabular}{|c|c|}
\hline Questions/answers & Distribution (n and \%) \\
\hline \multicolumn{2}{|c|}{ Knowledge on oral health } \\
\hline \multicolumn{2}{|c|}{ Do you know what bacterial plaque is? } \\
\hline Yes & $233(61.97 \%)$ \\
\hline No & $143(38.03 \%)$ \\
\hline Total & $376(100 \%)$ \\
\hline \multicolumn{2}{|c|}{ Do you know what dental caries is? } \\
\hline Yes & $358(95.21 \%)$ \\
\hline No & $18(4.79 \%)$ \\
\hline Total & $376(100 \%)$ \\
\hline \multicolumn{2}{|c|}{ Do you know what periodontal disease or periodontitis is? } \\
\hline Yes & $60(15.96 \%)$ \\
\hline No & $316(84.04 \%)$ \\
\hline Total & $376(100 \%)$ \\
\hline \multicolumn{2}{|c|}{ Do you think that dental caries is related to: } \\
\hline Lack of oral hygiene & $241(64.09 \%)$ \\
\hline Lack of oral hygieneand inadequate diet & $107(28.46 \%)$ \\
\hline Weak teeth & $25(6.65 \%)$ \\
\hline Family heritage & $3(0.80 \%)$ \\
\hline Total & $376(100 \%)$ \\
\hline \multicolumn{2}{|c|}{ Do you think that periodontal disease or periodontitis is related to: } \\
\hline Lack of oral hygiene & $144(38.30 \%)$ \\
\hline Lack of oral hygiene and inadequate diet & $65(17.29 \%)$ \\
\hline Weak teeth & $115(30.58 \%)$ \\
\hline Family heritage & $22(5.85 \%)$ \\
\hline Did not answer & $30(7.98 \%)$ \\
\hline Total & $376(100 \%)$ \\
\hline \multicolumn{2}{|c|}{ Have you already been given guidelines on oral hygiene? } \\
\hline Yes & $344(91.49 \%)$ \\
\hline No & $32(8.51 \%)$ \\
\hline Total & $376(100 \%)$ \\
\hline \multicolumn{2}{|c|}{ If yes, who guided you into oral hygiene? } \\
\hline Surgeon-dentist & $272(66.34 \%)$ \\
\hline Parents & 94 (22.93\%) \\
\hline Media & $28(6.83 \%)$ \\
\hline Friends/parents & $16(3.90 \%)$ \\
\hline *Students marked more than one alternative & $410(100 \%)$ \\
\hline \multicolumn{2}{|c|}{$\begin{array}{l}\text { Do you think it is possible to prevent dental caries and periodontal disease } \\
\text { by visiting the surgeon-dentist periodically? }\end{array}$} \\
\hline Yes & $339(90.16 \%)$ \\
\hline No & $37(9.84 \%)$ \\
\hline Total & $376(100 \%)$ \\
\hline
\end{tabular}

\begin{tabular}{|c|c|}
\hline \multicolumn{2}{|c|}{ Have you already been informed about the fluoride benefits? } \\
\hline Yes & $260(69.15 \%)$ \\
\hline No & $116(30.85 \%)$ \\
\hline Total & $376(100 \%)$ \\
\hline \multicolumn{2}{|c|}{ Behaviour and practices regarding oral hygiene } \\
\hline \multicolumn{2}{|c|}{ Which oral hygiene instruments do you use? } \\
\hline Toothbrush & $28(7.45 \%)$ \\
\hline Toothbrush and dentifrice & $76(20.21 \%)$ \\
\hline Toothbrush, dentifriceand dental floss & $272(72.34 \%)$ \\
\hline Total & $376(100 \%)$ \\
\hline \multicolumn{2}{|c|}{ Which type of toothbrush do you use? } \\
\hline Soft-bristled & $197(52.39 \%)$ \\
\hline Medium-bristled & $163(43.35 \%)$ \\
\hline Hard-bristled & $16(4.26 \%)$ \\
\hline Total & $376(100 \%)$ \\
\hline \multicolumn{2}{|c|}{ How often do you change your toothbrush? } \\
\hline Every 3 months & $325(86.44 \%)$ \\
\hline Every 6 months & $51(13.56 \%)$ \\
\hline Total & $376(100 \%)$ \\
\hline \multicolumn{2}{|c|}{ How often do you brush your teeth a day? } \\
\hline Once to twice & $68(18.08 \%)$ \\
\hline Three times or more & $308(81.92 \%)$ \\
\hline Total & $376(100 \%)$ \\
\hline \multicolumn{2}{|c|}{ Do you use dental floss? } \\
\hline Yes & $159(42.29 \%)$ \\
\hline Sometimes & $173(46.01 \%)$ \\
\hline No & $44(11.70 \%)$ \\
\hline Total & $376(100 \%)$ \\
\hline \multicolumn{2}{|c|}{ If you do not use dental floss, what are the reasons? } \\
\hline I do not know how to use it & $17(38.64 \%)$ \\
\hline I feel pain & $12(27.27 \%)$ \\
\hline My gum bleeds & $7(15.91 \%)$ \\
\hline It is expensive & $8(18.18 \%)$ \\
\hline Total & $44(100 \%)$ \\
\hline \multicolumn{2}{|c|}{ Do you use mouthwash? } \\
\hline Yes & $137(36.44 \%)$ \\
\hline Sometimes & $166(44.15 \%)$ \\
\hline No & $73(19.41 \%)$ \\
\hline Total & $376(100 \%)$ \\
\hline \multicolumn{2}{|c|}{ Do you drink soft drinks? } \\
\hline Yes & $342(90.96 \%)$ \\
\hline No & $34(9.04 \%)$ \\
\hline Total & $376(100 \%)$ \\
\hline \multicolumn{2}{|c|}{ How often do you drink soft drinks a day? } \\
\hline Once to twice & $232(61.70 \%)$ \\
\hline 3 to 4 times & $58(15.43 \%)$ \\
\hline More than 4 times & $52(13.83 \%)$ \\
\hline Never & $34(9.04 \%)$ \\
\hline Total & $376(100 \%)$ \\
\hline \multicolumn{2}{|c|}{$\begin{array}{l}\text { Do you consume sweets, soft drinks, candies, chewing gums, chocolate or } \\
\text { cookies between the meals? }\end{array}$} \\
\hline Yes & $167(44.42 \%)$ \\
\hline Sometimes & $158(42.02 \%)$ \\
\hline No & $51(13.56 \%)$ \\
\hline Total & $376(100 \%)$ \\
\hline \multicolumn{2}{|c|}{ Do you drink coffee with sugar between the meals? } \\
\hline Yes & $117(31.12 \%)$ \\
\hline Sometimes & $84(22.34 \%)$ \\
\hline No & $175(46.54 \%)$ \\
\hline Total & $376(100 \%)$ \\
\hline
\end{tabular}




\section{DISCUSSION}

Schools play an important role in the development of a systematic and continuous work for health promotion [6], enabling gathering several students at favourable ages in the same location for learning preventive measures [18]. In view of this, the school's role is not limited to providing education to students only, but also to creating ways to motivate them to educate themselves by allowing the development of their perception and conscious attitudes regarding their own health care.

Considering that adolescence is a phase of exposure to risks and new discoveries as well as a period of internal and interpersonal conflicts, many studies highlight the importance of better knowing the characteristics and specificities [1-3,9] of the teenagers. They are opposers, walk in groups, follow fashion, and worry about their body and look [19]. To think about the adolescent's health means to understand the several ways of thinking about and living adolescence [20].

The educational process on oral health acting as a transformer of attitudes can promote changes in the individual's life and society's reality $[21,22]$. It is necessary to implement efficient educational programs to previously assess the habits and level of knowledge of the target population, in this case, school students. Therefore, the present study was aimed at assessing the knowledge, behaviour and practices of students regarding oral health in order to determine preventive measures and actions in the environment where they are inserted.

In the present study, $54.26 \%$ of the students were female and $45.74 \%$ male. According to Lisboa \& Abegg [23], women are more concerned with physical appearance as they are very influenced by the existing social and cultural patterns, which contributes to them having more care about their body, which has repercussion on their habits and behaviour regarding oral health.

With regard to the use of healthcare services by school students, $88.30 \%$ visited a dentist, with $68.09 \%$ doing it within 1 year or less and 20.21\% more than 1 year, whereas $11.70 \%$ did not answer this question. These data reveal a relatively low adhesion to dental treatments in the 1-year period, with lack of motivation being one of the factors which might explain these results among the students. Vasquez et al. [9] evaluated the reasons given by adolescents for not adhering dental treatment and concluded that different priorities are involved. For instance, orthodontic appliance was found to strongly stimulate the interest and establishment of oral health priorities among teenagers. Regular appointments to dentists are of key importance, since this can be an indicator of oral and general health of the individuals [24]. Macek et al. [25] found that children who had visited dentists and undergone prophylactic procedures in the past 12 months had the best oral health conditions. Guidelines on oral hygiene should be provided by the practitioner, which encourages the patients to improve their self-care and motives them to return periodically $[26,27]$. Therefore, in the present work, the guidelines given to the students through lectures also aimed to encourage visits to surgeondentists as a preventive way to reduce the rates of bacterial plaques and oral problems.

It is known that transforming knowledge on health issues into healthy behaviours is a challenge task, mainly in situations in which there is a positive diagnosis of oral health impairment. One of the main challenges is to know how to motivate students and invest in the educational process $[9,28]$. Educational actions to promote oral health by encouraging self-care should identify sources of motivation and forms of personal satisfaction for mainly reinforcing related information, thus consolidating the acquired knowledge so that the effect of these 
actions does not disappear over time [29].

Knowledge on the aetiology of dental caries and periodontal disease is of key importance for preventing them from occurring. In this context, the surgeon-dentist should be aware of the patients' level of knowledge and seek to guide them by providing clear information. The results have shown that $61.97 \%$ of the students had knowledge on bacterial plaque, $95.21 \%$ on dental caries and only $15.96 \%$ on periodontal disease. In general, individuals have different knowledge on oral hygiene methods and diet recommended for prevention of dental caries and periodontal disease as a result of their education level, socio-economic profile, level of interest and learning opportunity [8]. Orsi et al. [30] assessed the habits and knowledge of school students regarding oral health and concluded that an educational preventive program achieved the objective of transmitting knowledge to this population, but there are still many points to be clarified. These same observations are valid for the study on this issue as the majority of students did not know about important information on dental caries and periodontal disease, including methods of oral hygiene, mainly those regarding the correct use of dental floss.

Based on the results found, one can observe that although school students have knowledge on oral hygiene, it is basic and rather poor. In fact, all students stated that they brushed their teeth daily, with $18.8 \%$ performing oral hygiene once to twice a day and $81.92 \%$ three or more times a day. A relatively low number of students used only toothbrush for their oral hygiene (7.45\%), whereas $11.70 \%$ used no dental floss at all or did it sometimes $(46,01 \%)$. In order to minimise such problems, the students were given oral hygiene kits containing toothbrush, dental floss and dentifrice while lectures for motivating and guiding them on how to perform oral hygiene correctly were administered. Several authors reported the importance of motivating children to improve their daily habits of oral hygiene $[31,32]$, concluding that it is fundamental to brush teeth three times a day for prevention of oral diseases, in association with the use of dental floss and/or dental tape to remove bacterial plaque from inter-proximal regions [33].

In a study with adolescents, Davoglio et al. [22] found that only $31.90 \%$ of them used dental floss daily. Our results have shown that $42.29 \%$ of the students used dental floss, 46.01 sometimes and $11.70 \%$ did not. Among the students not using dental floss, $15.91 \%$ reported that they did not use it because of gingival bleeding, $38.64 \%$ because they did not know how to use it, $27.27 \%$ because of pain and $18.18 \%$ because dental floss was too expensive. A probable explanation for these results might be the lack of guidelines on how to use dental floss correctly, although $91.49 \%$ of the students reported that they had already been given guidelines on oral hygiene. Another explanation might be the fact that daily tooth brushing is a more consolidated habit than the use of dental floss. It is relatively common to distribute toothbrushes to students in educational programs or schools, which does not happen with dental floss. Dental floss could also be distributed routinely, since the universal access to it is a strategy which has been encouraged by the Ministry of Health through a collective approach for health promotion and dental caries prevention [22,34]. In this sense, Neves et al. [35] believe that in addition to educational-preventive programs in schools and healthcare units, there is the need to adopt strategies making oral instruments available to low socio-economic population.

According to Gonçalves et al. [13], the majority of the patients think that tooth brushing is a preventive method against caries, but the prevention of periodontal disease is rarely known. In the present study, 64.09\% and $38.30 \%$ of the students reported the lack of oral hygiene as the main aetiological factor 
of, respectively, dental caries and periodontal disease. The results have also shown that surgeon-dentist was considered by the students as the main responsible for providing oral hygiene guidelines (66.34\%). Teixeira et al. [4] found that $50 \%$ of the adults living in a riverside community had already been given guidelines on oral health by a surgeon-dentist. Campos et al. [36] reported that the participation of dentists in schools for oral health education is usually limited to specific-content lectures, with the practitioners not remaining linked to the school. In this context, there emerges the need for strengthening initiatives to enable an effective approximation between surgeon-dentists and children, including families and teachers, in order to change behaviours regarding oral health as well as to implement and maintain healthy habits [31, 37]. Educational guidelines for students enable the transmission of acquired knowledge to their families and society, thus making them promoters of health as well [3840].

Among the students evaluated, 86.44\% reported that they consumed sweets, soft drinks, candies, chewing gums, chocolates or cookies between the meals. Coffee with sugar was also often consumed between the meals (53.46\%). These data are similar to those found by Teixeira et al. [4], who reported the use of refined sugar by $75 \%$ of the adults and consumption of soft drinks by $100 \%$ of the children living in the riverside community. These results demonstrate that parents should also be guided on their children's diet. Pregnant women, when well guided, can be an agent to reproduce the information on prevention, thus helping in the maintenance of preventive habits within the family [5].

The increased consumption of sugar is associated with a high prevalence of dental caries, therefore the DMFT index is elevated in the population [41,42]. In addition to tooth brushing, there should be changes in the children's diet habits to promote their oral health [6]. Thus, preventive measures to revert these results, such as dietetic counselling to prevent and maintain oral health, lectures on adequate food and rational use of sugar by encouraging the need for healthier nutrition, have been performed so that dietetic habits can be acquired during childhood and maintained as a nutritional pattern in the future $[6,41,43]$.

Although knowledge on oral health alone does not ensure a lasting behavioural change, this is an important factor for stimulating the incorporation of healthy habits. The majority of children and adolescents remain 4-5 hours a day at school, a period of time in which the learning process is established and family habits can be influenced. That is why the present study on this group of students is important, since it is possible to create new habits or modify the existing ones in this phase of life. It should also be taken into account that these school students are those who spread such knowledge within the context of their community, sometimes being the only source of information. Moreover, their community is poor and people there have little access to information as well as to oral healthcare [6].

Again, one can highlight the importance of motivation in the preventive educational process $[14,15,27]$. For achieving successful control and prevention of oral diseases, one should tailor the habits and behaviours of the school students by seeking to motivate and change them in order to improve their health conditions. In this context, surgeon-dentists and their team play a key role in guiding and encouraging patients so that their oral hygiene can be performed efficiently and frequently [12]. The proposed programs should be aimed at the needs and difficulties of the community served [44], and even after their implementation, it is necessary to follow up them longitudinally for evaluation of the outcomes.

Considering that the occurrence of some 
oral problems such as dental caries may be associated with socio-economic issues [45], we believe that public school students can exhibit worse oral health conditions. In this context, it is very important to address oral health issues in children attending public schools. Therefore, one can emphasise the need to create and implement educational activities on a permanent basis for public schools in order to reduce social inequalities in both oral health conditions and access to preventive guidelines [1].

\section{CONCLUSION}

One can conclude the following:

- School students have knowledge on educational and preventive methods for oral health, but with some deficiencies;

- The majority of the school students were given guidelines on how to avoid oral problems by a surgeon-dentist;

- It is necessary to emphasise the importance of using dental floss in the educational programs in order to change behaviours and practices of school students regarding oral health.

\section{REFERENCES}

1. Oliveira RCN, Souza JGS, Oliveira CC, Oliveira LFB, Pelino JEP, Martins AMEBL, et al. Acesso a informações sobre como evitar problemas bucais entre escolares da Rede Pública de Ensino. Ciênc. Saúde Coletiva. 2015 Jan;20(1):85-94. doi: http://dx.doi.org/101590/1413-81232014201.00032014.

2. Moreira PVL, Rosenblatt A, Passos IA. Prevalência de cárie em adolescentes de escolas públicas e privadas na cidade de João Pessoa, Paraíba, Brasil. Ciênc. Saúde Coletiva. 2007 Set-0ut;12(5):1229-36. doi:http://dx.doi. org/10.1590/S1413-81232007000500020. ID: lil-459452.

3. Flores EMTL, Drehmer TM. Conhecimentos, percepções, comportamentos e representaç̃ões de saúde e doença bucal dos adolescentes de escolas públicas de dois bairros de Porto Alegre. Ciênc. Saúde Coletiva. 2003;8(3):743-52. doi: http://dx.doi.org/10.1590/S1413-81232003000300008.

4. Teixeira SC, Cerqueira MN, Ferreira APP, Rocha DM, Naressi SCM. Comunidade Beira-rio: primeiro relato sobre condição bucal, hábitos de higiene e dieta alimentar. Cienc Odontol Bras. 2009 Jan/Mar;12(1):6-14. doi: http://dx.doi.org/10.14295/bds.2009.v12i1.246.

5. Reis DM, Pitta DR, Ferreira HMB, Jesus MCP, Moraes MEL, Soares MG Educação em saúde como estratégia de promoção de saúde bucal em gestantes. Ciênc Saúde Coletiva. 2010;15(1): 269-76. doi: http://www.redalyc. org/articulo.oa?id063012432028.

6. Rêgo HMC, Barcellos DC, Perote LCCC, Cavalheiro K, Huhtala MFRL, Gonçalves SEP, et al. Oral health longitudinal evaluation of students from a Public School after guidance and implementation of preventive measures. BrazDent Sci. 2012;15(4):41-8.

7. Oliveira RCN, Souza JGS, Oliveira CC, Oliveira LFB, Popoff DAV, Martins AMEBL, et al. Acesso a orientações de higiene bucal entre escolares da rede pública de ensino. Rev Odontol UNESP.2014 Nov/Dez;43(6):1-10. http://dx.doi. org/10.1590/1807-2577.1042

8. Gomes APM, Silva EG, Gonçalves SHF, Huhtala MFRL, Martinho FC, Gonçalves SEP, et al. Relationship between patient's education level and knowledge on oral health preventive measures. Int Dent Med J Adv Res. 2015;:1-7. doi:10.15713/ins.idmjar.6.

9. Vasquez FL, Cortelazzi KL, Gonçalo CS, Bulgareli JV, Guerra LM, Tagliaferro ESP, et al. Estudo qualitativo sobre as justificativas de adolescentes para a não adesão ao tratamento odontológico. Ciênc Saúde Coletiva. 2015 Jul|20(7):1-11. doi: org/10.1590/1413-81232015207.04502014.

10. Kwan SY, Petersen PE, Pine CM, Borutta A.. Health-promoting schools: an opportunity for oral health promotion. Bull World Health Organ. 2005 Sep;83(9):677-85. Epub 2005 Sep 30.

11. Al-jundi SH, Hammad M, Alwaeli H. The efficacy of a school-based caries preventive program: a 4-year study. Int J Dent Hygiene. $2006 \mathrm{Fev} ; 4(1): 30-4$. doi:10.1111/j.1601-5037.2006.00156.x.

12. Bardal PAP, Olympio KPK, Bastos JRM, Henriques JFC, Buzalaf MAR. Educação e motivação em saúde bucal - prevenindo doenças e promovendo saúde em pacientes sob tratamento ortodôntico. Dental Press J Orthod. 2011 May/Jun;16(3):95-102

13. Gonçalves PC, Vinholis AHC, Garcia PPNS, Corona SAM, Pereira OL. Considerações sobre programas de controle de placa. Robrac. 1998;7(23):36-9.

14. Arnett GM, Worley MC. The treatment motivation survey: defining patient motivation for treatment. Am J Orthod Dentofacial Orthop. 1999 Mar;115(3):233-8. doi: https://doi.org/10.1016/S0889-5406(99)70323-9.

15. Barker T. Patient motivation. Dent Update. 1999 Dec;26(10):453-6.

16. Chou TT, Ferreira NS, Kubo CH, Silva EG, Huhtala MFRL, Gonçalves SEP, et al. Evaluation of the knowledge and behavior of dental treatment in patients for caries, periodontal disease and oral hygiene. RPG Rev Pós Grad. 2011;18:140-7.

17. Sorensen K, Van den Broucke S, Fullam J, Doyle G, Pelikan J, SlonskaZ, et al. Consortium Health Literacy Project European. Health literacy and public health: a systematic review and integration of definitions and models. BMC Public Health. 2012 Jan 25;12:80. doi: 10.1186/1471-2458-12-80.

18. Tai BJ, Jiang H, Du Mq, Peng B. Assessing the effectiveness of a school-based oral health promotion programme in Yichang City, China. Community Dent Oral Epidemiol. 2009 0ct;37(5):391-8. doi: 10.1111/.16000528.2009.00484.x.

19. Boeira GF, Salas MMS, Araújo DC, Masotti AS, Correa MB, Demarco FF Factors influencing dental appearance satisfaction in adolescents: a cross-sectional study conducted in Southern of Brazil. Braz J Oral Sci. 2016;15(1):8-15.

20. Senna SRCM, Dessen MA. Contributions of human development theories to a contemporary concept of adolescence. Psic Teor e Pesq. 2012 Jan/ Mar;28(1):101-8. doi: http://dx.doi.org/10.1590/S0102-37722012000100013. 
21. Costa ICC, Fuscella MAP. Educação e saúde: importância da integração dessas práticas na simplificação do saber. Rev Ação Coletiva. 1999;2(3):45-7.

22. Davoglio RS, Aerts DRGC, Abegg C, Freddo SL, Monteiro L. Fatores associados a hábitos de saúde bucal e utilização de serviços odontológicos entre adolescentes. Cad Saúde Pública. 2009 Mar;25(3):655-67.

23. Lisbôa IC, Abegg C. Hábitos de higiene bucal e uso de serviços odontológicos por adolescentes e adultos do Município de Canoas, Estado do Rio Grande do Sul, Brasil. Epidemiol Serv Saúde. 2006;15(4):29-39.

24. Kirkevang LL, Wenzel A. Risk indicators for apical periodontitis. Community Dent Oral Epidemiol. 2003 Fev;31(1):59-67. doi:10.1034/j.16000528.2003.00032x

25. Macek MD, Wagner ML, Goodman HS, Manz MC, Marrazzo ID. Dental visits and access to dental care among Maryland schoolchildren. J Am Dent Assoc. 2005 Apr;136(4):524-33. doi: https://doi.org/10.14219/jada. archive.2005.0210.

26. Kay E, Locker D. A systematic review of the effectiveness of health promotion aimed at improving oral health. Community Dent Health. 1998 Sep;15(3):132-44.

27. Garcia PPNS, Dinelli W, Serra MC. Elaboração de um programa de educação e de motivação do paciente para retorno periódico. Robrac. 2000 Jun; $9(27): 37-40$.

28. Saba-Chujfi E, Silva ECQ, Saba MEC, Sarian R. Avaliação de métodos de motivação/educação em higiene bucal aplicados em adolescentes de 12 a 16 anos de idade. RG0. 1992 Mar-Abr;40(2):87-90

29. Pauletto ARC, Pereira MLT, Cyrino EG. Saúde bucal: uma revisão crítica sobre programações educativas para escolares. Cien Saúde Coletiva. 2004:9(1):121-30.

30. Orsi VME, Pereira AA, Flório FM, Souza LZ, Boaretto P,Pinheiro PPS Agosteneli SMC. Hábitos e conhecimentos de escolares sobre saúde bucal. RG0.2009 Jul-Set:57(3):291-6.

31. Aquilante AG, Almeida BS, Castro RFM, Xavier CRG, Peres SHCS, Bastos JRM. A importância da educação em saúde bucal para pré-escolares. Rev Odontol UNESP. 2003;32(1):39-45

32. Nunes VH, Perosa GB. Cárie dentária em crianças de 5 anos: fatores sociodemográficos, lócus de controle e atitudes parentais. Ciênc Saúde Coletiva. 2017 Jan;22(1):191-200.

33. Pereira AA, Sundefeld MLMM, Arcieri RM, Garbin CAS, Moimaz SAS, Saliba NA. Avaliação do programa de educação em saúde bucal da Faculdade de Odontologia de Araçatuba. Rev Paul Odont. 2005 Jul-Ago;27(3):28-31.
34. Antunes JLF, Narvai PC. Políticas de saúde bucal no Brasil e seu impacto sobre as desigualdades em saúde. Rev Saúde Pública. 2010 Abr;44(2):360-5.

35. Neves AM, Passos IA, Oliveira AFB. Estudo da prevalência e severidade de gengivite em população de baixo nível socioeconômico. Odontol Clin-Cient. 2010 Jan-Mar;9(1):65-71

36. Campos L, Bottan ER, Farias J, Silveira EG. Conhecimento e atitudes sobre saúde e higiene bucal dos professores do Ensino Fundamental de Itapema SC. Rev Odontol UNESP.2008:37(4):389-94.

37. Figueira TR, Leite ICG. Percepções, conhecimentos e práticas em saúde bucal de escolares. RG0.2008;56(1):27-32.

38. Mafrán MIC, Cosme YCR, Lobaina YL, Hung AMR, Torres AC. Instrucción educativa sobre salud bucal en la Escuela Primaria "Lidia Doce Sánchez". Medisan. 2010 Mar;14(2):232-42

39. Valarelli FP,Franco RM, Sampaio CC, Mauad C, Passos VAB, Vitor LLR, Machado MAAM, Oliveira TM. Importância dos programas de educação e motivação para saúde bucal em escolas: relato de experiência. Odontol Clín-Cient. 2011 Abr-Jun;10(2):173-6.

40. Faria FHP,Aguiar AC, Moura ATMS, Souza LMBM. Percepções de profissionais de saúde da família e de educação sobre a promoção da saúde no ambiente escolar. Rev APS. 2013 Abr-Jun;16(2):158-64.

41. Campos JADB, Zuanon ACC, Campos AG. Influência da alimentação e da nutrição na odontogênese e desenvolvimento de lesões de cárie dental. J Bras Odontopediatr Odontol Bebê. 2003 Mai-Jun;6(31):246-9.

42. Celeste RK, Nadanovsky P,Leon AP. Associação entre procedimentos preventivos no serviço público de odontologia e prevalência de cárie dentária. Rev Saúde Pública. 2007;41(5):830-8. doi: http://dx.doi.org/10.1590/ S0034-89102007000500018.

43. Tashima AY, Verrastro AP,Ferreira SLM, Wanderley MT. Correlação entre 0 aconselhamento dietético-nutricional e a promoção de saúde na clínica de Odontopediatria. J Bras Odontopediatr Odontol Bebê. 2000;3(16):11-7.

44. Kusma SZ, Moysés ST, Moysés SJ. Promoção da saúde: perspectivas avaliativas para a saúde bucal na atenção primária em saúde. Cad Saúde Pública. 2012;28 Sup:S9-S19.

45. Auad SM, Waterhouse PJ, Nunn JH, Moynihan PJ. Dental caries and its association with sociodemographics, erosion, and diet in schoolchildren from southeast Brazil. Pediatr Dent. 2009 May/Jun;31(3):229-35.

\section{Ana Paula Martins Gomes \\ (Corresponding address)}

Institute of Science and Technology

Avenida Engenheiro Francisco José Longo, 777, Jardim

São Dimas

São José dos Campos, SP, Brasil, CEP 12245-000

Date submitted: 2017 0ct 21

e-mail:paula@ict.unesp.br 